PENGARUH MINAT MEMBACA TERHADAP KEAKTIFAN BELAJAR PESERTA DIDIK PADA MATA PELAJARAN BAHASA INDONESIA KELAS IX SMP NEGERI 9 PADANG

\title{
PROPOSAL PENELITIAN
}

diajukan untuk memenuhi tugas perkuliahan

Metode Penelitian Pembelajaran Bahasa Indonesia

yang dibina oleh Prof. DR. Syahrul R., M.Pd.

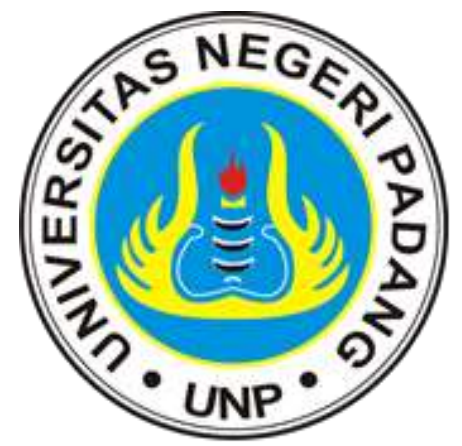

Elsa Dewi Saputri

(19016089)

PROGRAM STUDI PENDIDIKAN BAHASA DAN SASTRA INDONESIA

JURUSAN BAHASA DAN SASTRA INDONESIA DAN DAERAH

FAKULTAS BAHASA DAN SENI

UNIVERSITAS NEGERI PADANG

PADANG 
BAB I PENDAHULUAN

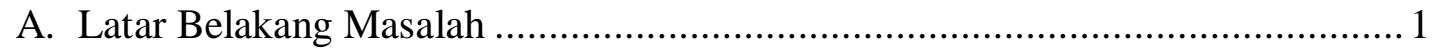

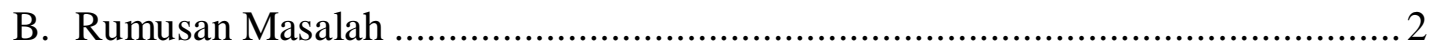

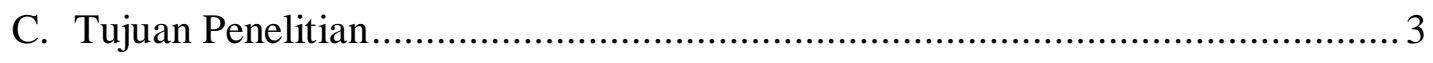

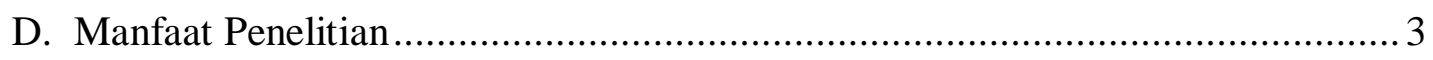

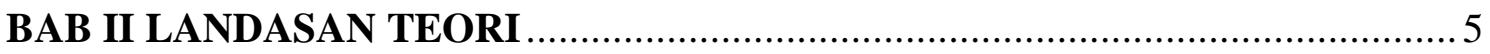

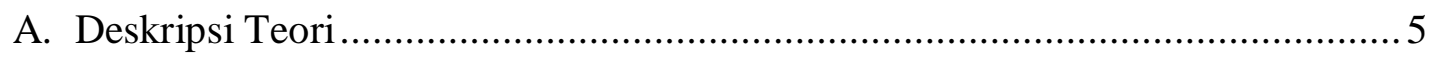

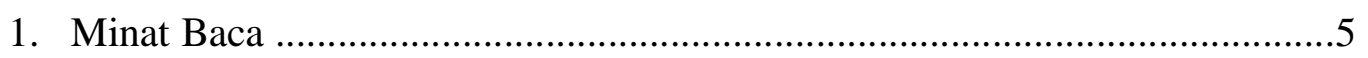

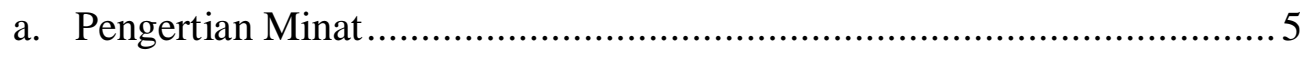

b. Pengertian Membaca ....................................................................... 7

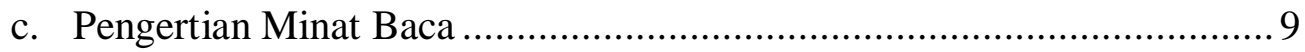

d. Faktor-faktor yang Mempengaruhi Minat Baca ................................. 11

2. Keaktifan Belajar Peserta Didik ........................................................ 12

a. Pengertian Keaktifan Peserta Didik ................................................ 12

b. Ciri-ciri Pesrta Didik yang Aktif ................................................ 13

c. Prinsip-prinsip Keaktifan Belajar ................................................. 14

d. Faktor-faktor yang Mempengaruhi Keaktifan Belajar........................ 15

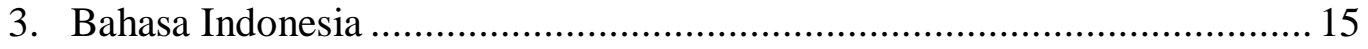

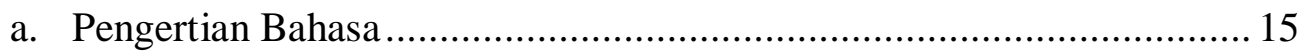

b. Pengertian Bahasa Indonesia ................................................... 16

c. Tujuan Pembelajaran Bahasa Indonesia........................................... 17

d. Standar Kompetensi Pelajaran Bahasa Indonesia .............................. 18

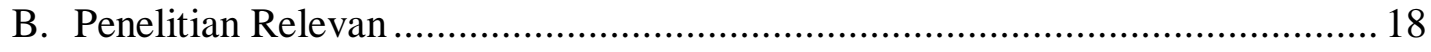

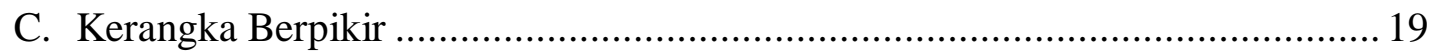

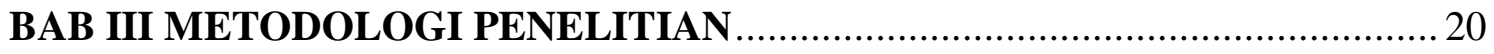

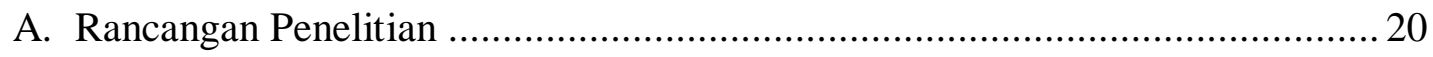

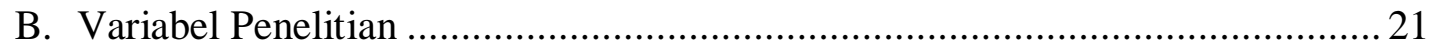


C. Populasi, Teknik Sampling, dan Sampel .................................................... 21

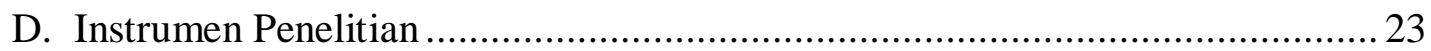

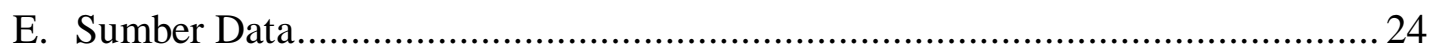

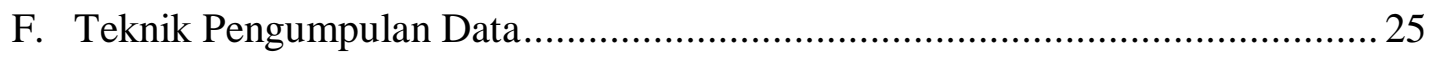

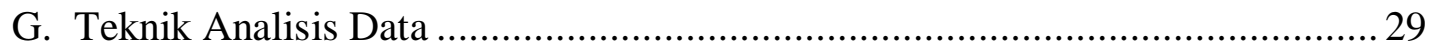

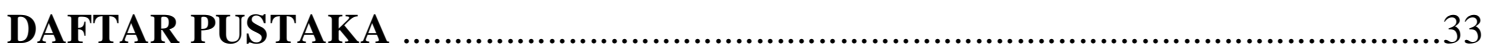




\section{BAB I \\ PENDAHULUAN}

\section{A. Latar Belakang Masalah}

Dalam pendidikan formal, belajar menunjukkan adanya perubahan yang sifatnya positif sehingga pada akhir pembelajaran akan dapat memiliki keterampilan dalam kecakapan (Ani Tri, 2010). Pendidikan bersifat dinamis, melalui pendidikan kita dapat mempertahankan atau mengembangkan nilai-nilai yang kita kehendaki sesuai dengan usaha-usaha pengembangan manusia seutuhnya ( Mia, 2017). Salah satu usaha yang digunakan untuk mewujudkan tujuan tersebut dengan melihat tingkat minat membaca dan keaktifan belajar siswa saat proses pembelajaran. Saat proses membaca terlibat beberapa faktor, yakni faktor internal dan faktor eksternal (Dinata Oni, 2017). Faktor internal yang dimaksud salah satunya disebutkan minat (Slameto, 2017). Selain minat membaca salah satu untuk mewujudkan suasana belajar atau proses pembelajaran agar peserta didik aktif dalam mengembangkan potensinya tersebut dimulai dari keaktifan belajar siswa dalam proses pembelajaran (Mia, 2017). Salah satu upaya yang dapat dilakukan untuk meningkatkan minat belajar siswa adalah dengan menggunakan model pembelajaran yang menarik bagi siswa (Rosidah. 2017).

Salah satu penyebab lemahnya kemampuan berbahasa Indonesia adalah sebagian orang kurang menghargai bahasa Indonesia dan masih rendah minat baca (Sigit, 2017). Minat baca menjadi kunci penting bagi kemajuan suatu bangsa, karena penguasaan Iptek hanya dapat diraih dengan minat baca yang tinggi, bukan kegiatan menyimak atau mendengarkan (Suharmono, 2015). Buruknya minat baca siswa merupakan satu dari beberapa faktor penyebab rendahnya hasil belajar sehingga menyebabkan menurunnya mutu pendidikan (Rizqon, 2016). Minat membaca buku perlu ditumbuhkan sejak dini karena minat memiliki peranan yang sangat penting dalam kehidupan siswa dan mempunyai dampak yang besar terhadap sikap dan perilaku. Upaya meningkatkan minat baca pada anak-anak yang utama menjadi tanggung jawab orang tua. Alasannya karena orang tua berada pada lingkungan pendidikan pertama yaitu keluarga (Gilang, 2015). Menurut Mia (2020), kegiatan membaca akan menjadi lebih efektif jika siswa 
memiliki minat baca yang tinggi, namun kenyataannya minat baca masyarakat Indonesia masih tergolong rendah.

Dalam proses pembelajaran ketika siswa diminta untuk membaca buku saat pembelajaran Bahasa Indonesia berlangsung, terlihat beberapa siswa mengeluh karena teks yang dibaca terlalu panjang pada akhirnya siswa hanya membolak-balik halaman buku. Demikian ditemukan siswa lebih memilih berbicara dengan temannya daripada membaca. Hal ini disebabkan karena siswa kurang mengutamakan kegiatan membaca dalam kesehariannya, ketika memiliki waktu luang, ternyata siswa lebih memilih untuk bermain bersama teman-temannya (Firmansyah, 2018). Hal lain terlihat bahwa siswa juga belum memiliki inisiatif untuk membaca buku atas kemauannya sendiri. Biasanya, siswa baru membaca apabila diperintah oleh gurunya untuk membaca (Doman, 2010). Penelitian yang sejalan dengan permasalahan kemampuan membaca dikemukakan oleh Winda (2019) yang mengatakan bahwa minat baca masyarakat Indonesia, termasuk siswa-siswi, masih rendah. Lebih lanjut, Ahmadi (2010), Kirby, et al. (2010) \& Triatma (2016) mengungkapkan bahwa minat baca pada siswa kelas 1 SD masih rendah, tetapi makin tinggi tingkat sekolah siswa, makin terdapat hubungan antara minat baca dengan kemampuan menulis. Tidak hanya di kalangan siswa, mahasiswa juga memiliki minat baca yang rendah (Siswati 2010; Nurhaidah \& Musa, 2016).

\section{B. Rumusan Masalah}

Rumusan masalah merupakan rumusan pertanyan yang dicarikan jawaban melalui pengumpulan data. Bagian ini berisi pertanyaan lengkap dan rinci mengenai ruang lingkup masalah yang akan diteliti berdasarkan identifikasi dan pembatasan masalah. Rumusan masalah berfungsi sebagai penentu arah atau fokus dalam suatu penelitian. Penulis juga dapat menentukan jenis, sumber data, teknik pengumupulan data, dan instrumen penelitian yang relevan dengan penelitian melalui penentuan rumusan masalah.

Berdasarkan latar belakang di atas, maka rumusan masalah dalam penelitian ini adalah: Apakah ada pengaruh positif dan signifikan antara minat membaca terhadap hasil belajar peserta didik pada mata pelajaran Bahasa Indonesia di SMP Negeri 9 Padang? 


\section{Tujuan Penelitian}

Tujuan penelitian adalah uraian yang menyebutkan secara spesifik mengenai maksud atau tujuan yang hendak dicapai dari sebuah penelitian. Berdasarkan rumusan masalah di atas, maka tujuan penelitian ini adalah untuk menjelaskan pengaruh positif dan signifikan antara minat baca terhadap hasil belajar peserta didik pada mata pelajaran Bahasa Indonesia di SMP Negeri 9 Padang.

\section{Manfaat Penelitian}

Adapun manfaat yang diharapkan dari hasil penelitian ini adalah sebagai berikut :

\section{Secara Teoritis}

a. Penelitian ini diharapkan dapat memberikan sumbangan ilmiah atau sumbangan ilmu untuk memperluas pengetahuan pada dunia pendidikan.

b. Hasil penelitian ini diharapkan dapat mengembangkan khasanah keilmuan yang dimungkinkan dapat dijadikan acuan dalam penelitian selanjutnya, serta dapat menjadi referensi untuk menambah pengetahuan dalam pengoptimalan minat baca dan cara belajar aktif peserta didik terhadap keaktifan belajar.

\section{Secara Praktis}

\section{a. Bagi Kepala Sekolah SMP Negeri 9 Padang}

Hasil penelitian ini, sebagai bahan masukan dalam mengambil kebijakan yang tepat untuk meningkatkan mutu sekolah, agar menjadi sekolah yang unggul dalam mencetak peserta didik yang berprestasi dan mandiri dalam belajar.

b. Bagi Guru SMP Negeri 9 Padang

Hasil penelitian ini dapat memberikan sesuatu pengetahuan untuk lebih menumbuhkan minat baca terhadap keaktifan belajar peserta didik pada mata pelajaran Bahasa Indonesia, agar pembelajaran ini lebih mudah dipelajari dan digemari oleh peserta didik, dan juga sebagai referensi, evaluasi dan motivasi diri untuk perbaikan pembelajaran kedepannya.

c. Bagi Peserta Didik SMP Negeri 9 Padang Hasil penelitian ini dapat mendorong dalam mengembangkan minat baca terhadap keaktifan belajar peserta didik khususnya pada mata pelajaran Bahasa Indoensia sebagai bekal pengetahuan dimasa yang akan datang. 


\section{d. Bagi Peneliti Selanjutnya}

Hasil penelitian ini, diharapkan dapat digunakan sebagai bahan pertimbangan dan juga referensi terhadap penelitian selanjutnya, serta untuk menambah wawasan serta dapat mengetahui secara langsung proses pembelajaran yang baik melalui pengembangan minat baca terhadap keaktifan belajar peserta didik pada mata pelajaran Bahasa Indonesia.

e. Bagi Pembaca

Hasil penelitian ini, sebagai gambaran dan menambah pengetahuan tentang pengaruh minat baca terhadap keaktifan belajar peserta didik pada mata pelajaran Bahasa Indonesia. 


\section{BAB II \\ KAJIAN PUSTAKA}

\section{A. Deskripsi Teori}

\section{Minat Baca}

\section{a. Pengertian Minat}

Menurut Kamus Besar Bahasa Indonesia (KBBI, 2008), minat adalah kecenderungan hati yang tinggi terhadap sesuatu. Minat diartikan sebagai suatu kondisi yang terjadi apabila seseorang melihat ciri-ciri atau arti sementara situasi yang dihubungkan dengan keinginan- keinginan atau kebutuhan-kebutuhannya sendiri. Apa yang dilihat seseorang sudah tentu akan membangkitkan minatnya, sejauh apa yang dilihat itu mempunyai hubungan dengan kepentingannya sendiri. Hal ini menunjukkan minat merupakan kecenderungan jiwa seseorang kepada seseorang (disertai dengan perasaan senang), karena merasa ada kepentingan dengan sesuatu itu. Menurut Bernard, minat timbul tidak secara tiba-tiba atau spontan, melainkan timbul akibat dari partisipasi, pengalaman, kebiasaan pada waktu belajar dan bekerja. Minat akan selalu berkait dengan soal kebutuhan atau keinginan. Pentingnya menciptakan kondisi tertentu agar peserta didik selalu butuh dan ingin terus belajar (Sardiman, 2007).

Minat adalah suatu rasa ketertarikan pada suatu hal atau aktivitas, tanpa ada yang menyuruh. Kemampuan membaca dan minat membaca yang tinggi adalah modal dasar untuk keberhasilan peserta didik dalam suatu pembelajaran. Mengembangkan minat terhadap sesuatu pada dasarnya membantu peserta didik melihat bagaimana hubungan antara materi yang diharapkan untuk dipelajarinya dengan dirinya sendiri sebagai individu. Apabila peserta didik menyadari bahwa belajar merupakan suatu alat untuk mencapai beberapa tujuan yang dianggapnya penting dan juga sebagai hasil dari pengalaman belajarnya akan membawa kemajuan pada dirinya, kemungkinan besar peserta didik akan berminat dan termotivasi untuk mempelajarinya (Slameto, 2003).

Minat adalah keinginan dalam diri seseorang terhadap sesuatu obyek, tanpa adanya suatu perintah atau paksaan dari orang lain. Minat akan berkaitan 
dengan kebutuhan atau keinginan seseorang. Minat adalah modal yang mendasari dalam suatu keberhasilan.

Minat adalah kecenderungan yang tetap untuk memperhatikan dan mengenang beberapa kegiatan. Kegiatan yang diminati seseorang, diperhatikan terus-menerus yang disertai dengan rasa senang. Jadi berbeda dengan perhatian, karena perhatian sifatnya sementara (tidak dalam waktu yang lama) dan belum tentu diikuti dengan perasaan senang dan dari situlah diperoleh kepuasan (Slameto, 2015). Minat adalah suatu rasa lebih suka dan rasa ketertarikan pada hal atau aktivi tas, tanpa ada yang menyuruh. Minat pada dasarnya adalah penerimaan akan suatu hubungan antara diri sendiri dengan sesuatu di luar diri. Semakin kuat atau dekat hubungan tersebut, maka semakin besar minat (Slameto, 2015). Menurut Nasution (Noor, 2015) minat adalah suatu yang penting bagi seseorang dalam melakukan kegiatan dengan baik. Sebagai suatu aspek kejiwaan, minat bukan saja mewarnai perilaku seseorang, tetapi lebih dari pada itu minat mendorong orang untuk melakukan kegiatan dan menyebabkan seseorang menaruh perhatian dan merelakan dirinya untuk terikat pada suatu kegiatan. Sedangkan minat menurut Hidayat (Noor, 2015) adalah suatu hal yang bersumber dari perasaan yang berupa kecenderungan terhadap suatu hal sehingga menimbulkan perbuatanperbuatan atau kegiatan-kegiatan tertentu.

Secara sederhana minat berarti kecenderungan dan kegairahan atau keinginan yang tinggi terhadap sesuatu. Minat dipahami dan dipakai oleh orang selama ini dapat mempengaruhi kualitas hasil belajar. Ahira juga mengatakan minat besar pengaruhnya terhadap belajar, karena bila bahan pelajaran yang dipelajari tidak sesuai dengan minat siswa maka tidak ada daya tarik baginya (Ahira, 2019). Pelajaran yang menarik minat siswa, lebih mudah dipelajari dan disimpan dalam ingatan, karena minat menambah giat belajar. Suatu minat dapat diekspresikan melalui suatu pernyataan yang menunjukkan bahwa siswa lebih menyukai suatu hal dari pada hal lainnya, dapat pula dimanifestasikan melalui partisipasi dalam suatu aktivitas. Siswa yang memiliki minat terhadap subyek tertentu cenderung untuk memberikan perhatian yang lebih besar terhadap subjek tersebut (Slameto, 2015). Minat merupakan salah satu dimensi dari aspek 
afektif yang banyak berperan dalam kehidupan seseorang. Aspek afektif adalah aspek yang mengidentifikasi dimensidimensi perasaan dari kesadaran emosi, disposisi, dan kehendak yang mempengaruhi pikiran dan tindakan seseorang. Serta minat juga merupakan salah satu aspek motorik (penggerak) dalam diri seseorang untuk mewujudkan keinginan atau kebutuhan. Minat harus diwujudkan dalam bentuk berbagai usaha agar tujuan yang dimaksud dapat tercapai.

\section{b. Pengertian Membaca}

Membaca merupakan suatu proses yang dilakukan serta dipergunakan oleh pembaca untuk memperoleh pesan yang hendak disampaikan penulis melalui media kata-kata atau bahasa tulis. Membaca adalah memetik serta memahami arti atau makna yang terkandung di dalam bahan tulis (Alwi, 2005).

Menurut Crawley dan Mountain, membaca pada hakikatnya adalah suatu yang rumit yang melibatkan banyak hal, tidak hanya sekadar melafalkan tulisan, tetapi juga melibatkan aktivitas visual, berpikir, psikolinguistik, dan metakognitif. Sebagai proses visual, membaca merupakan proses menerjemahkan simbol tulis (huruf) kedalam kata- kata lisan. Sebagai suatu proses berpikir, membaca mencakup aktivitas pengenalan kata, pemahaman literal, interpretasi, membaca kritis, dan pemahaman kreatif. Pengenalan kata bisa berupa aktivitas membaca kata-kata dengan menggunakan kamus (Farida, 2011). Menurut Farida Aktivitas

yang sangat dianjurkan bagi semua orang adalah membaca, karena dengan membaca kita dapat memahami dan memaknai apa yang terkandung didalam bahan tulis. Klein mengemukakan bahwa definisi membaca adalah mencangkup sebagai berikut:

1) Membaca merupakan suatu proses

Membaca merupakan suatu proses dimaksudkan informasi dari teks dan pengetahuan yang dimiliki oleh pembaca mempunyai peranan yang utama dalam membentuk makna.

2) Membaca adalah strategis

Pembaca yang efektif menggunakan berbagai strategi membaca yang sesuai 
dengan teks dan konteks dalam rangka mengkonstruk makna ketika membaca.

3) Membaca merupakan interaktif

Orang yang senang membaca suatu teks yang bermanfaat, akan menemui beberapa tujuan yang ingin dicapainya, teks yang dibaca seseorang harus mudah dipahami sehingga terjadi interaksi antara pembaca dan teks.

Minat baca menjadi kunci penting bagi kemajuan suatu bangsa, karena penguasaan Ilmu Pengetahuan dan Teknologi (IPTEK) hanya dapat diraih dengan minat baca yang tinggi, bukan kegiatan menyimak atau mendengarkan (Suharmono, 2015).

Melalui membaca, informasi dan pengetahuan yang berguna bagi kehidupan dapat diperoleh. Orang yang melakukan aktivitas tentunya mempunyai tujuan yang ingin dicapai, demikian juga dalam kegiatan membaca. Seseorang yang membaca dengan suatu tujuan, cenderung lebih memahami dibandingkan dengan orang yang tidak mempunyai tujuan. Tujuan utama dalam membaca adalah untuk mencari serta memperoleh informasi, mencangkup isi, memahami makna bacaan.

Membaca membuat individu dapat meningkatkan kecerdasan, mengakses informasi dan juga memperdalam pengetahuan dalam diri seseorang. Semakin sering membaca buku, semakin luas pengetahuan yang individu miliki. Sebaliknya, semakin jarang membaca buku, pengetahuan yang individu miliki semakin terbatas (Ilham, 2016). Dalam Kamus Besar Bahasa Indonesia (KBBI), membaca adalah melihat serta memahami isi dari apa yang tertulis. Membaca merupakan suatu proses yang dilakukan serta dipergunakan oleh pembaca untuk memperoleh pesan yang hendak disampaikan penulis melalui media katakata/bahasa tulis. Dengan kata lain, membaca adalah memetik serta memahami arti atau makna yang terkandung di dalam bahan tulis. Menurut Nurhadi membaca adalah suatu proses yang kompleks dan rumit. Kompleks berarti dalam proses membaca terlibat berbagai faktor internal dan faktor eksternal pembaca. Faktor internal berupa intelegensi, minat, sikap, bakat, motivasi, tujuan membaca, dan lain sebagainya. Faktor eksternal bisa dalam bentuk sarana membaca, latar belakang sosial dan ekonomi, dan tradisi membaca. Rumit artinya faktor eksternal 
dan internal saling berhubungan membentuk koordinasi yang rumit untuk menunjang pemahaman bacaan (Oni, 2017). Hamijaya dkk, mengungkapkan bahwa membaca adalah aktivitas intelektual, emosional, dan spiritual. Oleh karena itu, kita harus berusaha memaksimalkan diri dengan suatu kesadaran terhadap makna membaca sebagai kegiatan yang mencerdaskan sekaligus mencerahkan (Oni, 2017). Hamijaya dkk juga menyatakan membaca menjadi kebutuhan,tidak membaca kehilangan kesempatan dan peluang. Membaca menjadikan pikiran sehat, daya ingat meningkat (Oni, 2017).

\section{c. Pengertian Minat Baca}

Darmono mengemukakan minat baca merupakan kecenderungan jiwa yang mendorong seseorang berbuat sesuatu terhadap membaca. Minat baca ditunjukkan dengan keinginan yang kuat untuk melakukan kegiatan membaca. Orang yang memiliki minat membaca yang tinggi senantiasa mengisi waktu luang dengan membaca (Darmono, 2001).

Minat baca adalah keinginan yang kuat disertai usaha-usaha seseorang untuk membaca. Orang yang mempunyai minat membaca yang kuat akan diwujudkannya dalam kesediaannya untuk mendapat bahan bacaan dan kemudian membacanya atas kesadarannya sendiri (Farida, 2011).

Membaca sebagai salah satu cara untuk menambah dan meningkatkan ilmu pengetahuan, memperluas pandangan, memperkaya informasi dan merangsang munculnya ide-ide baru. Seperti yang dikemukakan oleh Gray dan Rogers dalam Mudjito, bahwa dengan membaca seseorang dapat mengetahui halhal aktual yang terjadi di lingkungannya, memuaskan rasa ingin tahu dan meningkatkan minat pada sesuatu dengan lebih intensif (Nurdin, 2011).

Ebbers mengatakan minat membaca adalah interst atau ketertarikan digambarkan sebagai kekuatan yang melibatkan alokasi fokus, dan perhatian yang ekstra dan mengarah pada daya ingat. Minat terkait dengan rasa ingin tahu dan pengetahuan, minat meliputi diskusi dan kesenangan (Oni, 2017). Rahim menyatakan minat membaca akan terwujud melalui proses belajar, berlatih, dan 
mengalami. Minat membaca selalu disertai keinginan dan usaha-usaha untuk membaca (Oni, 2017). Rahim menyebutkan bahwa orang yang mempunyai minat baca yang kuat akan diwujudkannya dalam kesediaannya untuk mendapat bahan bacaan dan kemudian membacanya atas kesadarannya sendiri. Bahan bacaan yang dibaca meliputi surat kabar, majalah, buku pelajaran, buku pengetahuan di luar buku pelajaran, dan buku cerita (Ilham 2016). Menurut (Noor, 2015) Minat sebenarnya mengandung tiga unsur yaitu unsur kognisi (mengenal), emosi (perasaan), dan konasi (kehendak). Hidayat membagi ketiga unsur tersebut menjadi beberapa indikator yang menentukan minat seseorang terhadap sesuatu, antara lain:

1) Keinginan. Seseorang yang memiliki keinginan terhadap suatu kegiatan tentunya ia akan melakukan atas keinginan dirinya sendiri. Keinginan merupakan indikator minat yang datang dari dorongan diri, apabila yang dituju sesuatu yang nyata. Sehingga dari dorongan tersebut timbul keinginan dan minat untuk mengerjakan suatu pekerjaan.

2) Perasaan Senang. Seseorang yang memiliki perasaan senang atau suka dalam hal tertentu ia cenderung mengetahui hubungan antara perasaan dengan minat.

3) Perhatian Adanya perhatian merupakan konsentrasi atau aktivitas jiwa seseorang terhadap pengamatan, pengertian, dan sebagainya dengan mengesampingkan yang lain.

4) Perasaan Tertarik. Minat bisa berhubungan dengan gaya gerak yang mendorong kita cenderung atau rasa tertarik pada orang, benda, atau kegiatan ataupun bisa berupa pengalaman yang efektif yang dirangsang oleh kegiatan itu sendiri. Orang yang memiliki minat yang tinggi terhadap sesuatu akan terdapat kecenderungan yang kuat tertarik pada guru dan mata pelajaran yang diajarkan. Sehingga perasaan tertarik merupakan indikator yang menunjukkan minat seseorang.

5) Giat Belajar. Aktivitas di luar sekolah merupakan indikator yang dapat menunjukkan keberadaan minat pada diri siswa. 6. Mengerjakan Tugas. Kebiasaan mengerjakan tugas yang diberikan guru merupakan salah satu indikator yang menunjukkan minat siswa. 
6) Menaati Peraturan. Orang yang berminat terhadap pelajaran dalam dirinya akan terdapat kecenderungan-kecenderungan yang kuat untuk mematuhi dan menaati peraturan-peraturan yang ditetapkan karena ia mengetahui konsekuensinya. Sehingga menaati peraturan merupakan indikator yang menentukan minat seseorang.

\section{d. Faktor-faktor yang Mempengaruhi Minat Membaca}

Membaca Dawson dan Bamman dalam Fitriana (Elisabet, 2016 hal 26), mengemukakan prinsipprinsip yang mempengaruhi minat baca sebagai berikut.

1) Seseorang atau siswa dapat menemukan kebutuhan dasarnya lewat bahanbahan bacaan jika topik, isi, pokok persoalan, tingkat kesulitan, dan cara penyajiannya sesuai dengan kenyataan individunya. Isi dari bahan bacaan yang menarik dan sesuai dengan kebutuhan individu, merupakan salah satu faktor yang berpengaruh terhadap minat membacanya.

2) Kegiatan dan kebiasaan membaca dianggap berhasil atau bermanfaat jika siswa memperoleh kepuasan dan dapat memenuhi kebutuhankebutuhan dasarnya, yaitu rasa aman, status, kedudukan tertentu, kepuasan efektif dan kebebasan yang sesuai dengan kenyataan sertatingkat perkembangannya. Jika kegiatan membaca dianggapmenguntungkan seseorang, maka membaca merupakan suatu kegiatan yang dianggap sebagai salah satu kebutuhan hidupnya.

3) Tersedianya sarana buku bacaan dalam keluarga merupakan salah satu faktor pendorong terhadap pilihan bahan bacaan dan minat baca. Ragam bacaan yang memadai dan beraneka ragam dalam keluargaakan sangat membantu anak dalam meningkatkan minat baca.

4) Tersedianya sarana perpustakaan sekolah yang relatif lengkap dan sempurna serta kemudahan proses peminjamannya merupakan faktor besar yang mendorong minat baca siswa.

5) Adanya program khusus kurikuler yang memberikan kesempatan siswa untuk membaca secara periodik di perpustakaan sekolah sangatmendorong perkembangan dan peningkatan minat baca siswa. 
6) Saran-saran teman sekelas sebagai faktor eksternal dapat mendorong timbulnya minat baca siswa. Pergaulan teman dalam sekolah menjadi salah satu faktor penting dalm pembentukan minat. Siswa yang berminat terhadap kegiatan membaca, akan lebih sering mengajak temannya ikut melakukan kegiatan membaca baik di dalam kelasataupun perpustakaan sehingga memberikan pengaruh positif juga terhadap temannya.

7) Faktor guru yang berupa kemampuan mengelola kegiatan dan interaksi belajar mengajar, khususnya dalam program pengajaran membaca. Guru yang baik harus mengetahui karakteristik dan minat anak. Guru bisa menyajikan bahan bacaan yang menarik dan bervariasi supaya siswa tidak merasa bosan.

\section{Keaktifan Belajar Peserta Didik}

\section{a. Pengertian Keaktifan Belajar}

Keaktifan belajar terdiri dari dua kata yakni keaktifan (aktif) dan belajar, keaktifan adalah kata sifat yang berawalan "Ke" dan berakhiran "an". Siswa adalah suatu organisme yang hidup. Dalam dirinya terkandung banyak kemungkinan dan potensi yang hidup dan sedang berkembang. Dalam diri masingmasing siswa terdapat "prinsip aktif” yakni keinginan berbuat dan bekerja sendiri. Sehubungan dengan hal tersebut, sistem pembelajaran dewasa ini sangat menekankan kepada pendayagunaan asas keaktifan (aktivitas) dalam proses belajar dan pembelajaran untuk mencapai tujuan yang telah ditentukan (Oemar, 2009). Dalam KBBI Kamus Besar Bahasa Indonesia aktif berarti giat (bekerja, berusaha). Keaktifan diartikan sebagai hal atau keadaan dimana siswa dapat aktif. Setiap orang yang belajar harus aktif sendiri, tanpa ada aktivitas proses pembelajaran tidak akan terjadi. Menurut Sardiman tidak ada belajar kalau tidak ada aktivitas. Itulah sebabnya aktivitas merupakan prinsip atau asas yang sangat penting di dalam interaksi belajar mengajar (Sardiman, 2014 hal 95-96). Keaktifan adalah kegiatan yang bersifat fisik maupun mental, yaitu berbuat dan berfikir sebagai suatu rangkaian yang tidak dapat dipisahkan (Sardiman, 2015 hal 98). Thorndike mengemukakan keaktifan belajar siswa dalam belajar dengan 
hukum "law of exercise" nya menyatakan bahwa belajar memerlukan adanya latihan-latihan dan Mc Keachie menyatakan berkenaan dengan prinsip keaktifan mengemukakan bahwa individu merupakan "manusia belajar yang aktif selalu ingin tahue (Dimyati, 2009 hal 45).

Berdasarkan penjelasan diatas, dapat penulis simpulkan bahwa keaktifan belajar adalah suatu kegiatan fisik maupun mental yang dilakukan selama proses pembelajaran. Karena hakikatnya sifat manusia yang bergerak dan ingin tahu. Sudjana (2019 hal 61) menyatakan keaktifan siswa dapat dilihat dalam beberapa hal:

1) Turut serta dalam melaksanakan tugas belajarnya.

2) Terlibat dalam pemecahan masalah.

3) Bertanya kepada siswa lain atau guru apabila tidak memahami persoalan yang dihadapinya.

4) Berusaha mencari berbagai informasi yang diperlukan untuk pemecahan masalah.

5) Melaksanakan diskusi kelompok sesuai dengan petunjuk guru.

\section{b. Ciri-ciri Peserta Didik yang aktif}

Menurut Abu Ahmadi dan Widodo Supriyono (Mulyasa, 2002), untuk melihat terwujudnya keaktifan belajar dalam proses pembelajaran, terdapat beberapa indikator. Melalui indikator keaktifan belajar, dapat dilihat tingkah laku yang muncul dalam suatu proses belajar mengajar, yaitu: ${ }^{36}$

1) Keinginan, keberanian menampilkan minat, kebutuhan, permasalahannya.

2) Keinginan dan keberanian serta kesempatan untuk berpartisipasi dalam kegiatan persiapan, proses, dan kelanjutan belajar.

3) Penampilan berbagai usaha atau kekreatifan belajar dalam menjalani dan menyelesaikan kegiatan belajar mengajar sampai mencapai keberhasilannya.

4) Kebebasan atau keleluasaan melakukan hal tersebut tanpa tekanan guru atau pihak lainnya (kemandirian belajar). 
Peserta didik berperan sebagai subjek belajar selama proses pembelajaran di kelas, maka peserta didik harus aktif dalam pembelajaran. Peserta didik diberikan kesempatan untuk mencari dan menemukan sendiri apa saja yang akan dipelajarinya, juga berkesempatan untuk mengembangkan kemampuan keterampilan yang dimilikinya.

\section{c. Prinsip-prinsip Keaktifan Belajar}

Prinsip aktivitas belajar menurut Sardiman (2014, hal 97-99) digolongkan menjadi dua pandangan, yaitu:

1) Menurut pandangan Ilmu Jiwa Lama John Locke dengan konsepnya Tabularasa, mengibaratkan jiwa (psyche) seseorang bagaikan kertas putih yang tidak bertulis. Kertas putih ini kemudian akan mendapatkan coretan atau tulisan dari luar. Terserah kepada unsur dari luar yang akan menulis, mau ditulis warna merah atau hijau, konsep semacam ini kemudian ditransfer ke dalam dunia pendidikan. Siswa diibaratkan kertas putih, sedangkan unsur dari luar yang menulis adalah guru. Dalam hal ini terserah guru mau dibawa kemana, mau diapakan siswa itu, karena gurulah yang member dan mengatur isinya. Dengan demikian aktivitas didominasi oleh guru sedang siswa bersifat fasif menerima begitu saja. Guru menjadi seorang yang adikuasa di dalam kelas.

2) Menurut pandangan Ilmu Jiwa Modern Aliran ilmu jiwa yang tergolong modern akan menerjemahkan jiwa manusia sebagai sesuatu yang dinamis, memiliki potensi dan energi sendiri. . Oleh karena itu, secara alami anak didik itu juga bisa menjadi aktif, karena adanya motivasi dan dorongan oleh bermacam-macam kebutuhan. Anak didik dipandang sebagai oranganisme yang mempunyai potensi untuk berkembang. Oleh karena itu tugas pendidik adalah membimbing dan menyediakan kondisi agar anak didik mengembangkan bakat dan potensinya. Dalam hal ini, anaklah yang beraktivitas, berbuat dan harus aktif sendiri. Berdasarkan kedua prinsip diatas jelas bahwa aktivitas belajar itu dalam pembelajaran sangat penting karena tanpa adanya aktivitas dalam belajar tujuan yang ingin dicapai tidak akan optimal seperti kita harapkan. 


\section{d. Faktor-faktor yang Mempengaruhi Keaktifan Belajar}

Keaktifan belajar peserta didik dalam proses pembelajaran dapat merangsang dan mengembangkan bakat yang dimilikinya, peserta didik juga dapat berlatih untuk berfikir kritis, dan dapat memecahkan permasalahan-permasalahan dalam proses pembelajaran. Upaya guru dalam meningkatkan cara belajar aktif peserta didik yaitu guru berperan dengan merekayasa sistem pembelajaran secara sistematis, sehingga merangsang keaktifan peserta didik dalam proses pembelajaran. Kegiatan-kegiatan guru yang dapat mempengaruhi keaktifan peserta didik menurut Moh. Uzer Usman (Nugroho, 2016) adalah:

1) Memberikan motivasi atau menarik perhatian peserta didik, sehingga mereka berperan aktif dalam kegiatan pembelajaran.

2) Menjelaskan tujuan instruksional (kemampuan dasar kepada peserta didik).

3) Mengingatkan kompetensi belajar kepada peserta didik.

4) Memberikan stimulus (masalah, topik, dan konsep yang akan dipelajari).

5) Memberikan petunjuk kepada peserta didik cara mempelajari.

6) Memunculkan aktifitas, partisipasi peserta didik dalam kegiatan pembelajaran.

7) Memberikan umpan balik (feedback).

8) Melakukan tagihan-tagihan kepada peserta didik berupa tes sehingga kemampuan peserta didik selalu terpantau dan terukur.

9) Menyimpulkan setiap materi yang disampaikan diakhir pembelajaran. Keaktifan dapat ditingkatkan dan diperbaiki dalam keterlibatan peserta didik pada saat belajar.

Berhasil tidaknya pembelajaran di sekolah bergantung pada aktif tidaknya peserta didik dalam belajar. Keaktifan ini bukan tentang aktif tidak mendengarkan guru ketika diberikan penjelasan, ramai dengan peserta didik lain, namun aktif yang berkualitas yang ditandai banyaknya respon dari peserta didik, banyaknya pertanyaan atau jawaban seputar materi yang dipelajari dan ide-ide yang berhubungan dengan konsep materi yang dipelajari.

\section{Bahasa Indonesia}

\section{a. Pengertian Bahasa}


Dalam arti luas, bahasa iyalah alat yang dipakai manusia untuk memberi bentuk kepada sesuatu yang hidup dijiwanya, sehingga di ketahui orang. Jadi disini termasuk juga mimiek (gerak muka), panto mimiek (gerak anggota). Dalam arti umum, bahasa ialah pernyataan perasaan jiwa dengan kata yang dilisankan atau yang ditulis (Ngalim, 1997).

Menurut pemakaianya, bahasa dibedakan atas dua macam, yakni bahasa lisan dan bahasa tulis. Bahasa yang asli ialah bahasa yang diucapkan atau bahasa lisan, karena sebelum mendapat menulis, manusia sudah mampu berkomunikasi dengan suara yang mengandung arti. Baru kemudian timbul bahasa tulis. Namun demikian, hal itu tidak berarti bahwa bahasa lisan lebih penting daripada bahasa tulis atau sebaliknya. Akan tetapi keduanya memegang peranan penting sebagai alat komunikasai, karena keduanya saling membantu (wirjosoedarmo, 1984)

Menurut Mulyati dalam Sitti Aminah bahasa terdiri dari kata-kata atau kumpulan kata, yang mempunyai makna yang disusun secara alfabetis atau menurut urutan abjad disertai penjelasan artinya dan kemudian dibukukan menjaddi sebuah kamus atau leksikon (Sitti, 2020). Dari beberapa pengertian bahasa yang telah dijelaskan diatas maka dapat ditarik kesimpulan bahwa bahasa adalah sarana komunikasi angota masyarakat dalam menyampaikan ide atau perasaan baik secara tertulis maupun lisan.

\section{b. Pengertian Bahasa Indonesia}

Seiring berkembangan ilmu dan teknologi menunjukan bahwa Bahasa Indonesia sebagai bahasa nasional yang sangat berperan sebagai sarana komunikasi, dibidang akademik peranan bahasa Indonesia telah ditunjukan dalam berbagai disiplin ilmu melalui bentuk-bentuk tulisan ilmiah seperti makalah dan skripsi. Begitu pentingnya bahasa sebagai sarana komunikasi batasan atau pengertian bahasa adalah sarana komunikasi anggota masyarakat dalam menyampaikan ide dan perasaan secara lisan atu tulis (Sinta, 2018).

Bahasa Indonesia adalah alat komunikasi yang dipergunakan masyarakat untuk keperluan sehari-hari, misalnya bekerjasama dan berinteraksi. Bahasa Indonesia merupakan bahasa nasional dan bahasa resmi di Indonesia. Bahasa 
Nasional adalah Bahasa yang menjadi bahasa standar karena perkembangan sejarah, kesepakatan bangsa, atau ketetapan perundang-undang. Sebagai Bahasa Nasional, Bahasa Indonesia tidak mengikat pemakainya untuk sesuai nonresmi, santai dan bebas, bahasa Indonesia memiliki memiliki fungsi tertentu berdasarkan kebutuhan pemakaiannya, sebagai alat untuk mengekspresikan diri, sebagai alat untuk berkomunikasi, sebagai alat untuk mengadakan interaksi dan beradaptasi sosial dan lingkungan (Ayu, 2019).

\section{c. Tujuan Pembelajaran Bahasa Indonesia}

Tujuan pembelajaran bahasa indonesia menurut Ayu Septiana (2019) adalah sebagai berikut:

1) Bahasa Indonesia memiliki peran sentral dalam perkembangan intelektual, sosial dan emosional peserta didik dan merupakan penunjang keberhasilan dalam mempelajari semua bidang studi. Pembelajaran bahasa diharapkan membantu peserta didik mengenal dirinya sendirinya, budayanya, dan budaya orang lain, mengemukakan gagasan dan perasaan, berpartisipasi dalam masyarakat yang mengunakan bahasa tersebut, dan menemukan serta mengunakan kemampuan analitif dan imaginative yang ada dalam dirinya.

2) Bahasa Indonesia adalah sarana komunikasi, untuk saling berbagi pengalaman, saling belajar dari yang lain, serta untuk menigkatkan kemampuan intelektual dan kesastraan Indonesia. Adapun harapan pelajaran bahasa Indonesia agar siswa mampu mengembangkan pengetahuan, keterampilan berbahasa, dan bersikap positif terhadap bahasa Indonesia, serta menghargai manusia dan nilai-nilai kemanusiaan.

3) Pembelajaran bahasa Indonesia diarahkan untuk menigkatkan kemampuan peserta didik untuk berkomunikasi dalam bahasa Indonesia yang baik dan benar, baik secara lisan maupun tulis, serta menumbuhkan apresiasi hasil karya kesastraan manusia Indonesia.

4) Agar peserta didik menghargai dan bangga menggunakan bahasa Indonesia sebagai bahasa persatuan dan bahasa Negara. 


\section{d. Standar Kompetensi Pelajaran Bahasa Indonesia}

Standar kompetensi mata pelajaran bahasa Indonesia merupakan kualifikasi kemampuan minimal peserta didik yang mengambarkan penguasaan pengetahuan, keterampilan berbahasa, dan sikap positif terhadap bahasa dan sastra Indonesia. Standar kompetensi ini merupakan dasar bagi peserta didik untuk memahami dan merespon situasi lokal, regional, nasional, dan global. Pembelajaran bahasa Indonesia diarahkan untuk menigkatkan kemampuan peserta didik untuk berkomunikasi dalam bahasa Indonesia dengan baik dan benar, baik secara lisan maupun tulis.

Dengan standar kompetensi mata pelajaran bahasa Indonesia ini bertujuan agar peserta didik memiliki kemampuan sebagai berikut:

1) Berkomunikasi secara efektif dan efisien sesuai dengan etika yang berlaku secara lisan maupun tulis.

2) Menghargai dan bangga mengunakan bahasa Indonesia sebagai bahasa persatuan dan bahasa Negara.

3) Menggunakan bahasa Indonesia dengan tepat dan kereatif untuk berbagai tujuan.

4) Menggunakan bahasa Indonesia untuk menigkatkan kemampuan intelektual, serta kematangan emosional dan sosial.

5) Menikmati dan memanfaatkan karya sastra untuk memperluas wawasan, memperhalus budi pekerti, serta menigkatkan pengetahuan dan kemampuan berbahasa.

6) Menghargai dan membanggakan sastra Indonesia sebagai Khazanah budaya dan intelektual manusia Indonesia.

Berdasarkan kesimpulan diatas maka standar kompetensi mata pelajaran Bahasa Indonesia bagi peserta didik berkomunikasi secara efektif dan efisien, menghargai dan bangga mengunakan bahasa Indonesia dengan tepat, menigkatkan kemampuan intelektual, memperluas wawasan, serta menigkatkan pengetahuan dan kemampuan berbahasa, menghargai dan membangakan sastra Indonesia.

\section{B. Penelitian Relevan}

Penelitian yang dilakukan ini berbeda dengan penelitian-penelitian sebelumnya. Penelitian terdahulu yang relevan dengan penelitian ini adalah sebagai berikut:

1) Penelitian yang dilakukan oleh Ghazi Luthfia Agusdina (2018) dengan judul "Pengaruh Minat Baca terhadap Hasil Belajar Afektif dan Psikomotor Siswa Kelas V SD Negeri 2 Botoran Tulungagung”. Berdasarkan hasil penelitian menunjukkan 
minat baca memiliki pengaruh yang signifikan terhadap hasil belajar afektif dan psikomotor.

2) Penelitian yang dilakukan oleh Nur Ma'arif (2010) dengan judul "Pengaruh Minat Baca terhadap Prestasi Belajar Siswa di MA Abadiyah Gabus Pati Kelas XI". Berdasarkan hasil penelitian dapat disimpulkan bahwa minat baca berpengaruh terhadap prestasi belajar siswa di MA Abadiyah Gabus Pati kelas XI.

3) Penelitian yang dilakukan oleh Nurhikma (2017) dengan judul "Pengaruh Minat dan Kebiasaan Membaca terhadap Tingkat Prestasi Peserta Didik di SMP Negeri 2 Pangkajene". Berdasarkan hasil penelitian dapat disimpulkan bahwa terdapat pengaruh positif dan signifikan antara minat baca dan kebiasaan membaca secara bersama-sama terhadap prestasi belajar di SMP Negeri 2 Pangkajene.

\section{Kerangka Berfikir}

Kerangka berfikir merupakan kerangka konseptual tentang bagaimana teori berhubungan, dengan ini berbagai faktor yang telah diidentifikasi sebagai masalah yang diteliti (Sugiono, 2012).

Minat baca terkandung unsur perhatian, kemauan, dorongan dan rasa senang untuk membaca. Perhatian bisa dilihat dari perhatiannya terhadap kegiatan membaca, mempunyai kemauan yang tinggi untuk membaca, dorongan dan rasa senang yang timbul dari dalam diri maupun dari pengaruh orang lain. Semua itu merupakan aktivitas yang dilakukan dengan penuh ketekunan dan cenderung menetap.

Keaktifan belajar merupakan salah satu hal yang penting dalam proses belajar mengajar. Karena dengan adanya keaktifan saat proses pembelajaran maka peserta didik akan memiliki rasa antusias mengikuti proses pembelajaran. Keaktifan belajar peserta didik dalam belajar dapat dilihat dari keikutsertaannya dalam melaksanakan tugas belajarnya. 


\section{BAB III \\ METODOLOGI PENELITIAN}

\section{A. Rancangan Penelitian}

\section{Pendekatan Penelitian}

Suatu penelitian tentunya perlu disusun suatu rancangan penelitian, agar penelitian berjalan sesuai dengan yang diharapkan dan tidak keluar dari jalur yang sudah ditetapkan serta menggunakan pendekatan dan jenis penelitian yang tepat untuk mengatasi permasalahan yang diteliti.

Suatu kegiatan penelitian diperlukan suatu metode penelitian, agar hasil penelitian yang diperoleh dapat dipertanggung jawabkan. Penelitian ini menggunakan pendekatan kuantitatif. Penelitian kuantitatif adalah penelitian yang pada dasarnya menggunakan pendekatan deduktif, artinya pendekatan yang berangkat dari suatu kerangka teori, gagasan para ahli, maupun pemahaman peneliti berdasarkan pengalamannya, kemudian dikembangkan menjadi permasalahan beserta pemecahan yang diajukan untuk memperoleh pembenaran (Verifikasi) dalam bentuk dukungan data empiris di lapangan.

Pendekatan kuantitatif dikatakan kuantitatif karena data penelitian yang dikumpulkan berbentuk angka-angka dan bermaksud menguji hipotesis tertentu. Data yang telah diperoleh dalam penelitian ini selanjutnya diolah sesuai dengan kesimpulan sementara yang dibuat (hipotesis) yang diinginkan yaitu mencari pengaruh antara variabel satu dengan variabel lainnya (Sukardi, 2014).

Peneliti menggunakan pendekatan kuantitatif karena ingin mengetahui ada tidaknya pengaruh variabel bebas terhadap variabel terikat dan besarnya pengaruh variabel bebas terhadap variabel terikat dan mengukur hasilnya melalui analisis statistik inferensial. Statistik inferensial adalah tehnik statistik yang digunakan untuk menganalisis data sampel dan hasilnya diberlakukan untuk populasi (Sugiono, 2010).

\section{Jenis Penelitian}

Jenis penelitian yang digunakan adalah jenis penelitian korelasional. Penelitian korelasional merupakan kegiatan penelitian yang melibatkan tindakan pengumpulan 
data guna menentukan apakah ada hubungan dan seberapa kuat tingkat hubungan antara dua atau lebih variabel tersebut. Adapun hubungan dalam penelitian ini adalah: Pengaruh minat membaca terhadap hasil belajar peserta didik pada mata pelajaran Bahasa Indonesia di SMP Negeri 9 Padang.

\section{B. Variabel Penelitian}

Variabel merupakan istilah yang tidak pernah lepas dalam setiap jenis penelitian. Menurut Suharsimi Arikunto, variabel adalah obyek penelitian atau apa yang menjadi titik perhatian suatu penelitian (Arikunto, 2010). Sedangkan menurut Sugiyono variabel penelitian adalah segala sesuatu yang berbentuk apa saja yang ditetapkan oleh peneliti untuk dipelajari sehingga diperoleh informasi tentang hal tersebut, kemudian ditarik kesimpulannya (Sugiono, 2012).

Menurut hubungan antara satu variabel dengan variabel yang lain maka macammacam variabel dalam penelitian dapat dibedakan menjadi :

1. Variabel Bebas

Variabel bebas adalah variabel yang mempengaruhi atau yang menjadi sebab perubahannya atau timbulnya variabel dependen (terikat). Variabel ini biasanya disimbolkan dengan variabel "X". Variabel bebas dalam penelitian ini adalah minat membaca.

2. Variabel Terikat

Variabel terikat adalah variabel yang dipengaruhi atau yang menjadi akibat karena adanya variabel bebas. Variabel ini biasanya disimbolkan dengan variabel "Y". Variabel terikat dalam penelitian ini adalah keaktifan belajar.

\section{Populasi, Teknik Sampling, dan Sampel}

1. Populasi

Populasi merupakan hal yang sangat penting untuk memberikan batasan yang jelas tentang obyek yang akan diteliti. Menurut Sugiyono populasi adalah wilayah generalisasi yang terdiri ata objek atau subjek yang mempunyai kualitas dan karakteristik tertentu yang ditetakan peneliti untuk dipelajari dan kemudian ditarik kesimpulannya (Sugiyono, 2010). Sedangkan menurut Suharsimi Arikunto, populasi 
adalah keseluruhan subyek penelitian. Apabila seseorang ingin meneliti semua elemen yang ada dalam wilayah penelitian, maka penelitiannya merupakan penelitian populasi, studi atau penelitiannya juga disebut studi populasi atau studi sensus (Arikunto, 2010).

Populasi adalah jumlah dari keseluruhan objek (satuan-satuan/ individu-individu) yang karakteristiknya hendak diduga. Adapun populasi yang menjadi sasaran penelitian ini adalah siswa kelas IX SMP Negeri 9 Padang.

Tabel 3.1 Jumlah Populasi

\begin{tabular}{|c|c|c|}
\hline No & Kelas & Jumlah Siswa \\
\hline 1. & IX-1 & 31 Orang \\
\hline 2. & IX-2 & 31 Orang \\
\hline 3. & IX-3 & 32 Orang \\
\hline 4. & IX-4 & 32 Orang \\
\hline 5. & IX-5 & 33 Orang \\
\hline 6. & IX-6 & 32 Orang \\
\hline 7. & IX-7 & 32 Orang \\
\hline 8. & IX-8 & 32 Orang \\
\hline & Jumlah & 255 Orang \\
\hline
\end{tabular}

2. Sampel

Sampel adalah bagian dari jumlah dan karakteristik yang dimiliki oleh populasi tersebut (Sugiyono, 2010). Sampel ditentukan oleh peneliti berdasarkan pertimbangan masalah, tujuan, hipotesis, metode, dan instrumen penelitian, disamping pertimbangan waktu, tenaga, dan pembiayaan (Darmawan, 2014). Menurut pendapat Suharsimi dalam pengambilan sampel, apabila subyek kurang dari 100, lebih baik diambil semua. Tetapi jika jumlah subjek besar, dapat diambil antara 10-15\% atau 20\%-25\% atau lebih (Arikunto, 2010). Pada penelitian ini peneliti memilih untuk mengambil sampel sebanyak $25 \%$ dari 255 peserta didik $(25: 100) \times 255=64$ peserta didik, dalam penelitian ini peneliti menggunakan simple random sampling (sampling acak sederhana) dengan cara ordinal (tingkatan sama), maksudnya dalam simple 
random sampling semua kelas dalam populasi diberikan kesempatan untuk dijadikan sampel dengan cara diundi.

3. Teknik Sampling

Teknik sampling adalah suatu teknik memilih atau mengambil sampel yang dianggap peneliti memiliki ciri-ciri yang sesuai dengan yang diharapkan yaitu mempunyai kemampuan yang sama (Arikunto, 2010). Populasi yang berjumlah 255 orang peserta didik kelas IX yang dibagi menjadi 8 kelas. Cara yang ditempuh untuk menentukan sampel dalam penelitian ini adalah dengan menggunakan Simple Random Sampling atau Sampel Acak Sederhana. Simple Random Sampling atau Sampel Acak Sederhana merupakan teknik pengambilan sampel yang memberikan kesempatan yang sama kepada populasi untuk dijadikan sampel.

Tabel 3.2 Jumlah Sample Peserta didik Kelas IX

\begin{tabular}{|c|c|c|c|}
\hline No & Kelas & Jumlah & Jumlah Sampel \\
\hline 1. & IX-1 & 31 Orang & 8 Peserta Didik \\
\hline 2. & IX-2 & 31 Orang & 8 Peserta Didik \\
\hline 3. & IX-3 & 32 Orang & 8 Peserta Didik \\
\hline 4. & IX-4 & 32 Orang & 8 Peserta Didik \\
\hline 5. & IX-5 & 33 Orang & 8 Peserta Didik \\
\hline 6. & IX-6 & 32 Orang & 8 Peserta Didik \\
\hline 7. & IX-7 & 32 Orang & 8 Peserta Didik \\
\hline 8. & IX-8 & 32 Orang & 8 Peserta Didik \\
\hline \multicolumn{2}{|c|}{ Total } & 255 & 64 Peserta Didik \\
\hline
\end{tabular}

\section{Instrumen Penelitian}

Instrumen adalah alat atau fasilitas yang digunakan oleh peneliti dalam mengumpulkan data agar pekerjaannya lebih mudah dan hasilnya lebih baik, dalam artian lebih cermat, lengkap dan sistematis sehingga lebih mudah diolah. Sedangkan menurut 
Sugiyono, instrument penelitian adalah suatu alat yang digunakan mengukur fenomena alam maupun sosial yang diamati.

Instrumen dalam penelitian ini untuk mengetahui pengaruh minat baca terhadap keaktifan belajar peserta didik pada mata pelajaran bahasa indonesia di SMPN 9 Padang. Sebuah kualitas instrumen akan mempengaruhi kualitas sebuah penelitian. Kualitas instrumen dalam penelitian berkenaan dengan validasi. dan reliabilitas instrumen (Sugiono, 2012). Instrumen penelitian merupakan alat bantu penelitian dalam pengumpulan data.

Agar data penelitian mempunyai kualitas yang cukup tinggi, maka alat pengambilan datanya harus memenuhi syarat-syarat sebagai alat ukur yang baik. Adapun syarat-syaratnya adalah sebagai berikut:

1. Validitas

Validitas adalah suatu ukuran yang menunjukkan tingkat kevalidan suatu instrumen. Sebuah instrumen dikatakan valid apabila mampu mengukur apa yang diinginkan dan dapat mengungkap data dari variabel yang diteliti secara tepat. Tinggi rendahnya validitas instrumen menunjukkan sejauh mana data yang terkumpul tidak menyimpang dari gambaran tentang validitas yang dimaksud (Arikunto, 2010). Untuk menguji tingkat validitas instrumen, peneliti telah melakukan validitas dengan cara mengkonsultasikan instrumen penelitian dengan Bapak Germino Wahyu Broto, M.Si dan Ibu Nuzulunni'mah, M.Psi. Selain itu untuk menguji validitas empiris instrumen, peneliti mencobakan instrumen tersebut pada sasaran dalam penelitian, yakni pada satu kelas IX-6 sebanyak 32 peserta didik. Langkah ini disebut dengan kegiatan uji coba instrumen. Apabila data yang didapat dari uji coba setelah diproses dan analisis statistik serta sudah valid ini sudah sesuai dengan yang seharusnya, maka instrumennya sudah baik dan sudah valid.

2. Reliabilitas

Reliabilitas menunjukkan sesuatu instrumen cukup dapat dipercaya untuk digunakan sebagai alat pengumpulan data instrumen tersebut sudah baik. Instrumen yang sudah dapat dipercaya, yang reliabel akan menghasilkan data yang dapat dipercaya juga. Reliabilitas menunjukkan pada tingkat keterladanan sesuatu. 
Reliabel artinya, dapat dipercaya, jadi dapat diandalkan.

\section{E. Sumber Data}

Sumber data yang dimaksud disini adalah subjek darimana data penelitian diperoleh. Data yang digunakan dalam penelitian ini diperoleh dari orang-orang yang berperan langsung dalam proses pembelajaran di SMPN 9 Padang, melalui observasi dan angket. Peneliti berusaha untuk mendapatkan data-data yang bersumber dari data primer dan sekunder, sebagai berikut:

\section{Data Primer}

Sumber data primer adalah data yang langsung diperoleh dari sumber data pertama dilokasi penelitian atau obyek penelitian. Sumber data primer dari penelitian ini adalah peserta didik sebagai pelaku utama yang diteliti.

2. Data Sekunder

Data sekunder adalah data yang diperoleh tidak secara langsung pada sumber data pertama atau objek utama yang akan diteliti. Data sekunder dari penelitian ini datadata dokumentasi, arsip-arsip yang menunjang penelitian dan data-data lain yang relevan. Sumber data ini diperoleh dari informan:

a. Kepala sekolah sebagai orang yang bertanggung jawab terhadap sekolah yang dijadikan objek penelitian.

b. Dokumen sekolah, untuk mengetahui jumlah siswa, dan hasil belajar siswa.

\section{F. Teknik Pengumpulan Data}

Teknik pengumpulan data merupakan langkah yang paling strategis dalam penelitian, karena tujuan utama dari penelitian adalah mendapatkan data. Penelitian ini memakai beberapa teknik dalam mengumpulkan data- data yang dibutuhkan sebagai berikut:

1. Skala

Skala adalah kesepakatan yang digunakan sebagai acuan untuk menentukan panjang pendeknya interval yang ada dalam alat ukur, sehingga alat ukur tersebut bila digunakan dalam pengukuran akan menghasilkan data kuantitatif. Penelitian ini ada dua variabel yaitu minat baca dan keaktifan belajar, yang akan diukur menggunakan 
instrumen skala pengambilan data yang diberi skor atau bobot nilai pada tiap alternative jawaban responden, yaitu dengan mengubah data yang bersifat kuantitatif.

Langkah-langkah yang dilakukan dalam penyusunan instrumen adalah sebagai berikut:

a. Menentukan variabel yang diteliti

b. Menentukan indikator dari masing-masing variabel

c. Membuat daftar pertanyaan sesuai berdasarkan indikator untuk instrumen

d. Mengkonsultasikan daftar pertanyaan kepada dosen pembimbing

e. Menyebarkan instrumen kepada responden

Data mengenai instrumen skala peserta didik diperoleh dengan menggunakan skala Likert. Skala Likert digunakan untuk mengukur sikap, pendapat, dan persepsi seseorang atau kelompok orang tentang fenomena sosial. Item-item skala disajikan dalam bentuk tertutup dengan menyediakan 5 alternatif jawaban, yaitu:

a. $\mathrm{SS}=$ Sangat Sesuai

b. $\mathrm{S}=$ Sesuai

c. $\mathrm{TS}=$ Tidak Sesuai

d. STS = Sangat Tidak Sesuai

Tabel 3.3 Keterangan Skala Likert

\begin{tabular}{|c|c|c|c|c|}
\hline Pilihan/Sifat & SS & S & TS & STS \\
\hline Positif & 4 & 3 & 2 & 1 \\
\hline Negatif & 1 & 2 & 3 & 4 \\
\hline
\end{tabular}

Tabel diatas memaparkan pedoman skala pemberian skor atas tanya jawab atau pilihan responden dimana pada item favorable akan berbeda cara penilaian dengan unfavorable. Pada nilai favorable jika responden SS maka akan diberi skor tertinggi yaitu 4, jika responden $\mathrm{S}$ maka diberi skor 3, jika responden TS maka diberi skor 2, dan jika responden STS maka diberi skor terendah yaitu 1. Sedangkan pada nilai Unfavorable jika responden SS maka akan diberi skor terendah yaitu 1 , jika responden $\mathrm{S}$ maka akan diberi skor 2, jika responden TS 
maka diberi nilai 3, dan jika respoden STS maka akan diberi skor tertinggi yaitu 4.

Tabel 3.4 Instrumen Skala Minat Baca

\begin{tabular}{|c|c|c|c|c|c|}
\hline No & Pernyataan & SS & $\mathbf{S}$ & TS & STS \\
\hline 1. & $\begin{array}{l}\text { Saya tidak tertarik untuk membeli } \\
\text { buku bacaan tentang bahasa indonesia }\end{array}$ & & & & \\
\hline 2. & $\begin{array}{l}\text { Saya cepat mengalami bosan } \\
\text { ketika membaca buku }\end{array}$ & & & & \\
\hline 3. & $\begin{array}{l}\text { Karena kurangnya motivasi, saya } \\
\text { kurang semangat dalam membaca }\end{array}$ & & & & \\
\hline 4. & $\begin{array}{l}\text { Saya ingin membaca buku ketika } \\
\text { jam pelajaran kosong }\end{array}$ & & & & \\
\hline 5. & $\begin{array}{l}\text { Membaca bukan menjadi } \\
\text { kebutuhan saya }\end{array}$ & & & & \\
\hline 6. & $\begin{array}{l}\text { Saya jarang berusaha mencari } \\
\text { tahu terhadap hal yang baru saat } \\
\text { membaca }\end{array}$ & & & & \\
\hline 7. & $\begin{array}{l}\text { Membaca merupakan hal yang } \\
\text { penting bagi saya }\end{array}$ & & & & \\
\hline 8. & $\begin{array}{l}\text { Saya jarang berkunjung ke } \\
\text { perpustakaan untuk membaca buku }\end{array}$ & & & & \\
\hline 9. & $\begin{array}{l}\text { Saya aktif berkunjung ke } \\
\text { perpustakaan untuk membaca buku }\end{array}$ & & & & \\
\hline 10. & $\begin{array}{l}\text { Saya kurang suka mengoleksi } \\
\text { buku diluar buku pelajaran }\end{array}$ & & & & \\
\hline 11. & $\begin{array}{l}\text { Ketika ada acara bedah buku, } \\
\text { saya datang untuk membaca buku di } \\
\text { acara itu }\end{array}$ & & & & \\
\hline 12 . & $\begin{array}{l}\text { Saya tidak meluangkan waktu } \\
\text { untuk membaca di rumah }\end{array}$ & & & & \\
\hline
\end{tabular}




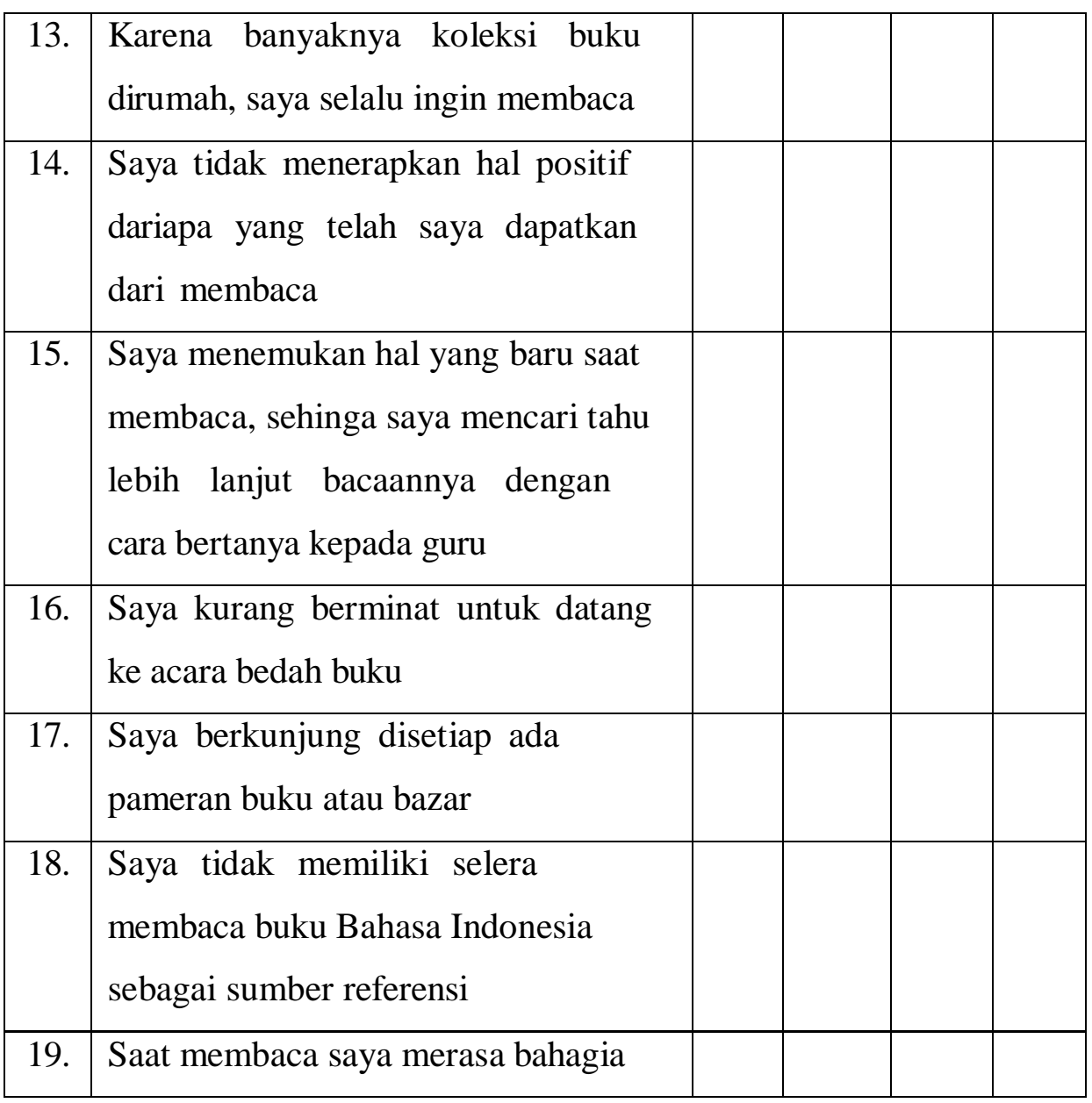

Tabel 3.5 Instrumen Skala Keaktifan Belajar

\begin{tabular}{|c|l|c|c|c|c|}
\hline No & \multicolumn{1}{|c|}{ Pernyataan } & SS & S & TS & STS \\
\hline 1. & $\begin{array}{l}\text { Saya malas mengikuti kegiatan } \\
\text { kelompok di kelas }\end{array}$ & & & \\
\hline 2. & $\begin{array}{l}\text { Saya berusaha menyelesaikan suatu } \\
\text { kegiatan belajar dengan baik }\end{array}$ & & & & \\
\hline 3. & $\begin{array}{l}\text { Saya memiliki kebebasan untuk } \\
\text { mengatur sendiri jadwal belajar }\end{array}$ & & & & \\
\hline 4. & $\begin{array}{l}\text { Saya tidak memiliki keinginan } \\
\text { untuk belajar }\end{array}$ & & & & \\
\hline 5. & $\begin{array}{l}\text { Saya berani bertanya pada saat } \\
\text { proses pembelajaran Bahasa Indonesia }\end{array}$ & & & & \\
\hline
\end{tabular}




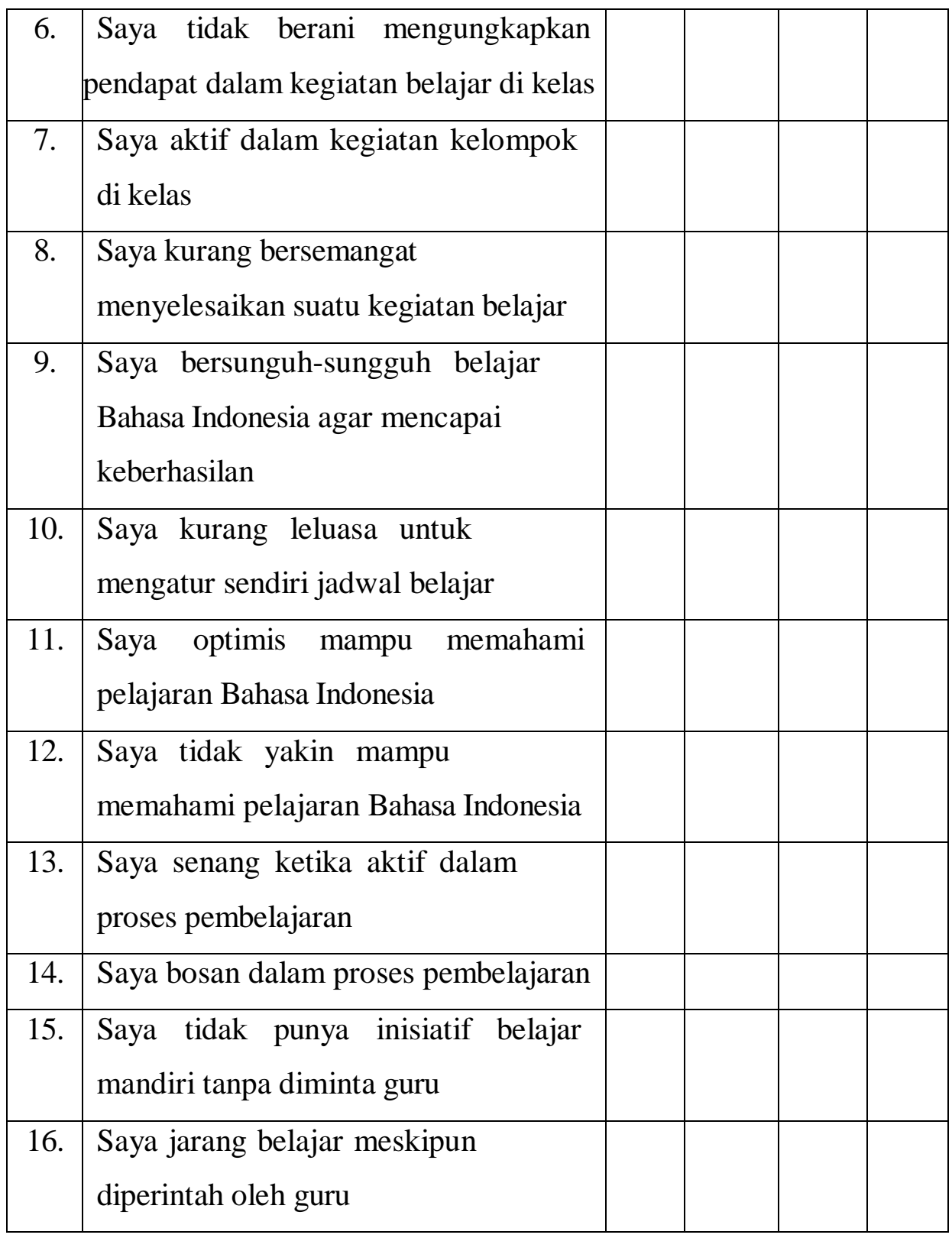

2. Observasi

Observasi adalah memperhatikan sesuatu dengan menggunakan mata atau biasa disebut pengamatan. Observasi dapat dilakukan dengan tes, kuesioner, rekaman gambar, dan rekaman suara. Observasi bisa dilakukan dengan 2 cara, yaitu sebagai berikut:

a. Observasi Sistematis

Observasi ini dilakukan oleh peneliti dengan menggunakan pedoman sebagai instrumen pengamatan yaitu dengan instrumen yang berisi sederetan indikator- 
indikator dari variabel minat baca dan keaktifan belajar peserta didik.

b. Observasi Non Sistematis

Observasi ini dilakukan oleh peneliti dengan tidak menggunakan instrumen. Secara langsung peneliti mengamati pembelajaran yang berlangsung di SMPN 9 Padang yang dilakukan ketika pra penelitian atau sebelum penelitian.

\section{Dokumentasi}

Metode dokumentasi yaitu mencari data mengenai hal-hal atau variabel yang berupa catatan, transkrip, buku, surat kabar, majalah, prasasti, notulen rapat, lengger, agenda, dan sebagainya. Dokumentasi dalam penelitian ini digunakan untuk memperoleh data tentang jumlah siswa di SMPN 9 Padang, jumlah guru, struktur organisasi, dan data nilai hasil belajar peserta didik.

\section{G. Teknik Analisis Data}

Analisis data merupakan kegiatan mengelompokkan data berdasarkan variabel dan jenis responden, mentabulasi data berdasrkan variabel dari seluruh responden, menyajikan data tiap variabel yang diteliti, melakukan perhitungan untuk menjawab rumusan masalah, dan melakukan perhitungan untuk menguji hipotesis yang telah diajukan. Pada suatu penelitian telah dibuat hipotesisnya yang perlu dibuktikan kebenarannya.

Setelah data terkumpul selanjutnya peneliti melakukan analisis atau pengolahan data yang diperoleh agar dapat digunakan menjawab permasalahan yang telah diajukan. Tahapan dalam mengolah data, yaitu:

1. Tahap Pengolahan Data

a. Pengklasifikasi data

Pengklasifikasi data dilakukan dengan mengelolakan aneka ragam jawaban kedalam kategori-kategori yang jumlahnya lebih terbatas. Pengklasifikasian kategori tersebut penyusunannya harus dibuat lengkap, agar tidak ada satupun jawaban responden yang tidak mendapat tempat dan kategori yang satu dengan yang lainnya tidak tumpang tindih. 


\section{b. Editing}

Memeriksa kembali data yang telah masuk ke responden mana yang relevan dan mana yang tidak relevan. Editing adalah pekerjaan mengoreksi atau melakukan pengecekan. Instrumen skala ditarik kembali serta diperiksa apakah setiap pertanyaan sudah dijawab, seandainya sudah dijawab apakah sudah benar.

c. Koding Koding adalah mengklasifikasikan jawaban-jawaban dari para responden kedalam kategori-kategori. Biasanya klasifikasi dilakukan dengan cara memberi tanda atau kode berbentuk angka pada masing- masing jawaban. Kode adalah isyarat yang dibuat dalam bentuk angka atau huruf yang memberikan petunjuk atau identitas pada suatu informasi atau data yang akan dianalisis. Pemberian kode dalam penelitian ini adalah Instrumen skala yang telah diperiksa diberi identitas sehingga dapat diketahui kelanjutan proses pengolahan data. Hasil dari koding dalam penelitian ini sebagai berikut:

1) Untuk variabel independen (X) yaitu: minat baca.

2) Untuk variabel dependen (Y), yaitu keaktifan belajar.

d. Tabulasi

Memasukkan data kedalam tabel-tabel dan mengatur angka-angka sehingga dapat dihitung jumlah kasus dalam beberapa kategori.

e. Penerapan data sesuai dengan pendekatan penelitian

Pengolahan data dengan menggunakan rumus-rumus yang ada sesuai dengan pendekatan penelitian yang diambil. Setelah data diolah dan

dimasukkan ke dalam tabel, selanjutnya adalah menganalisis atau menguji data tersebut dengan analisis kuantitatif atau statistik.

\section{Tahap Analisis Data}

Setelah data dihimpun, langkah selanjutnya adalah melakukan analisis data. Penelitian ini menggunakan teknik analisis data kuantitatif. Analisis data kuantitatif adalah analisis yang digunakan untuk mengolah data-data yang diwujudkan dengan angka. Adapun data-data atau hipotesis penelitian dapat dianalisis dengan menggunakan analisis regresi ganda. Analisis regresi ganda adalah suatu alat analisis 
peramalan nilai pengaruh dua variabel bebas atau lebih terhadap variabel terikat. Adapun langkah- langkah dalam analisis datanya sebagai berikut:

a. Analisis Inferensial

Teknik analisis data kuantitatif menggunakan statistik inferensial. Statistik Inferensial sering disebut juga statistik induktif atau statistik probabilitas. Statistik Inferensial adalah statistik yang dapat digunakan untuk menganalisis data sampel dan hasilnya diberlakukan untuk populasi.

b. Uji Prasyarat

Sebelum melakukan pengujian hipotesis, maka diperlukan uji prasyarat terlebih dahulu. Uji prasyarat tersebut meliputi uji normalitas dan uji linearitas, yaitu sebagai berikut:

1) Uji normalitas

Pengujian ini bermaksud untuk mengetahui normal atau tidaknya data yang diperoleh. Uji normalitas dilakukan dengan menggunakan Kolmogrov Smirnov dengan bantuan SPSS versi 16.0 for windows. Jika probabilitas $\geq$ 0,05 maka datanya dinyatakan berdistribusi normal, sebaliknya jika nilai probilitasnya $\leq 0,05$ maka datanya dinyatakan berdistribusi tidak normal. Uji ini dapat dilakukan dengan menggunakan bantuan program SPSS 16.0 for Windows.

2) Uji linearitas

Uji linearitas bertujuan untuk mengetahui apakah dua variabel mempunyai hubungan yang linier atau tidak. Dalam hal ini pengujian tersebut meliputi variabel $\mathrm{X}$ dengan $\mathrm{Y}$ dan data tersebut akan dikatakan linier jika:

a) Nilai signifikansi $\geq 0.05$ maka data tersebut linier

b) Nilai signifikansi $\leq 0.05$ maka data tersebut tidak linier

Hasil uji linieritas yang dilakukan peneliti dengan menggunakan bantuan SPSS 16.0 for Windows.

3) Uji Multikolinieritas

Uji multikolinieritas ini bertujuan untuk menguji apakah dalam model 
regresi ditemukan adanya korelasi antar variabel bebas. Model regresi yang baik seharusnya tidak terjadi korelasi diantara variabel bebas.

Hasil uji multikolinieritas yang dilakukan peneliti dengan menggunakan bantuan SPSS 16.0 for Windows. 


\section{DAFTAR PUSTAKA}

Abdulrahman. 2004. Meningkatkan Kemampuan Pemahaman dan Kemampuan Generalisasi Matematik Siswa SMA melalui Model Pembelajaran Berbalik. Bandung: Thesis UPI.

Agusdina, Ghazi Luthfia. 2018. Pengaruh Minat Baca terhadap Hasil Belajar Afektif dan Psikomotor Siswa Kelas V SD Negeri Botoran Tulungagung. Tulungagung: Skripsi.

Ahmadi, Abu dan Widodo Supriyono. 2004. Psikologi Belajar. Jakarta: PT Rineka Cipta.

Ahmadi, F. (2010). Meningkatkan minat membaca siswa sekolah dasar dengan metode Glenn Doman berbasis multimedia. Jurnal Penelitian Pendidikan. Vol. 2, No.1, h. 64-71.

Anisah, Nisfi dan Aninditya Sri Nugraheni. 2016. Korelasi antara Minat Baca dengan Prestasi Belajar Kelas V MIN Wonosari Gunungul Yogyakarta Tahun Pelajaran2015/2016. Al Bidayah, Jurnal Pendidikan Dasar Islam, Volume 8, Nomor 2.

Arikunto, Suharsimi. 2010. Prosedur Penelitian dan Pendekatan Praktis. Jakarta: Rineka Cipta. Ayu Setiani. 2019. Upaya Menigkatkan Kemampuan Membaca Nyaring Mengunakan Media Cerita Bergambar Pada Mata Pelajaran Bahasa Indonesia Untuk Siswa Kelas II SD Negeri 84 Kota Bengkulu. Bengkulu: IAIN Bengkulu.

Darmawan, Deni. 2014. Metode Penelitian Kuantitatif. Bandung: PT Remaja RosdaKarya.

Darmono. 2001. Manajemen dan Tata Kerja Perpustakaan Sekolah. Jakarta: Grasindo.

Dimyati dan Mudjiono. 2019. Belajar dan pembelajaran, Jakarata: Rineka Cipta.

Dimyati, M. 2001. Dilema Pendidikan Ilmu Pengetahuan: Cet.1. Malang: Ikatan Profesi Teknologi Pendidikan Indonesia.

Doman, G. (2010). Meningkatkan Minat Membaca Siswa Sekolah Dasar Dengan Metode Glenn Doman Berbasis Multimedia. Jurnal Penelitian Pendidikan Unnes. Vol. 2, No.1, h. 194 .

Elisabet Sukma Dewi, Skripsi. Pengaruh Konsep Diri, Keaktifan Belajar dan Minat Baca Literatur Terhadap Hasil Belajar Mata Pelajaran Akuntansi Siswa Kelas XII IPS Semester Ganjil SMA Negeri Seputih Mataram Tahun Pelajaran 2015/2016. 
Fakultas Keguruan dan Ilmu Pendidikan Universitas Lampung Bandar Lampung. 2016., hal 26.

Firmansyah, D. (2018). Analysis of Language Skills in Primary School Children (Study Development of Child Psychology of Language). Journal of Primary Education. Vol. 2, No. 1, h.68.

Gilang, 2015. Pengaruh Minat Baca Terhadap Prestasi Belajar IPS Siswa Kelas V SD SE GUGUS II Kasihan Bantul Tahun Ajaran 2014/2015. Jurnal Bahasa. Vol. 1, No. 1.

Hasan, Alwi dkk. 2005. Kamus Besar Bahasa Indonesia. Jakarta: Departemen Pendidikan Nasional Balai Pustaka.

Ilham Nur Triatma. Minat Baca Pada Siswa Kelas VI Sekolah Dasar Negeri Delegan 2 Prambanan Sleman Yoyakarta. E-jurnal Prodi Teknologi Pendidikan Vol. V Nomor 6 Tahun 2016.

Kirby, J.R., Ball, A., Geier, B.K., Parrila, R., \& Wade-Woolley, L. (2010). The development of reading interest and its relation to reading ability. Journal of Research in Reading, 34(3), 263280.

M. Ngalim Purwanto, Djeniah Alim. 1997. Metodologi Pengajaran Bahasa Indonesia Di Sekolah Dasar. Jakarta: PT Rosda Jayaputra.

Ma'arif, Nur. 2010. Pengaruh Minat Baca terhadap Prestasi Belajar Siswa di MA Abadiyah Gabus Pati Kelas XI. Surabaya: Skripsi.

Mia Anggun Rosalina, 2017. Analisis Keaktifan Siswa Kelas VII SMP Dharmawanita Pare Dalam Pembelajaran Pair Checks Pada Aritmatika Sosial. Simki-Techsain. Vol. 01. No, 03. Pp. 42.

Mia Zultrianti. 2020. Pengaruh Minat Baca Siswa Terhadap Hasil Belajar Pada Pelajaran Bahasa Indonesia di SD Negeri 1 Ciporang. Jurnal Riset Pedagogik. Vol. 4, No. 2, h. 198.

Mudjiono dan Dimyati. 2006. Belajar dan Pembelajaran. Jakarta: Rineka Cipta.

Mulyasa, E. 2002. Manajemen Berbasis Sekolah, Konsep Strategi dan Implementasi. Bandung: Remaja Rosda Karya. 
Noor Komari Pratiwi. Skripsi. Pengaruh Tingkat Pendidikan, Perhatian Orang Tua, dan Minat Belajar Siswa Terhadap Prestasi Belajar Bahasa Indonesia Siswa SMK Kesehatan di Kota Tangerang. Jurnal Pujangga Volume 1, Nomor 2, Desember 2015.

Nurdin. 2011. Pengaruh Minat Baca, Pemanfaatan Fasilitas dan Sumber Belajar Terhadap Prestasi Belajar IPS Terpadu SMP Negeri 13 Bandar Lampung. Jurnal Ekonomi dan Pendidikan, Vol. 8 Nomor 1.

Nurhaidah, M. \& Musa, I. (2016). Dampak rendahnya minat baca dikalangan mahasiswa PGSD Lampeuneurut Banda Aceh serta cara meningkatkannya. Jurnal Pesona Dasar. Vol. 3, No. 4, h. 1-11.

Nurhikma. 2017. Pengaruh Minat dan Kebiasaan Membaca terhadap Tingkat Prestasi Peserta Didik di SMP Negeri 2 Pangkajene. Makassar: Skripsi.

Ony Dinata. 2017. "Minat Baca Anak-anak di Kampoeng Baca Kabupaten Jember”. Jurnal Pendidikan Dasar. Vol. 3. Nomor 1.

Rahim, Farida. 2011. Pengajaran Membaca di Sekolah Dasar. Jakarta: Bumi Aksara.

Rahim, Farida. 2011. Pengajaran Membaca di Sekolah Dasar. Jakarta: Bumi Aksara.

Rizqon Musafir. 2016. Pengaruh Minat Baca Mahasiswa Terhadap Hasil Belajar Pada Mahasiswa Jurusan Bimbingan Konseling Islam IAI Darussalam Blokagung. Jurnal Pendidikan, Komunikasi dan Pemikiran Hukun Islam. Vol. VII, No. 2, h. 468.

Rosidah. 2017. Upaya Meningkatkan Minat Membaca Siswa Melalui Model Pembelajaran Kooperatif Tipe Tari Bambu pada Kompetensi Dasar Menanggapi Isi Cerita Secara Lisan di Kelas IV SD Negeri 067690 Medan Johor. Jurnal Bahasa Indonesia, Vol. 5 No.2, h. $98-106$.

Sardiman. 2007. Interaksi dan Motivasi Belajar Mengajar. Jakarta: RajaGrafindo Persada.

Sardiman. A. M. 2009. Interaksi dan Motivasi Belajar Mengajar. Jakarta: Raja Grafindo.

Sardiman. A. M. 2014. Interaksi dan Motivasi Belajar Mengajar. Jakarta: Raja Grafindo.

Sigit, Widiarto. 2017. Pengaruh Minat Baca dan Penguasaan Kosakata Terhadap Keterampilan Menulis Eksposisi. Jurnal Bahasa Indonesia, Vol. 3, No. 1, h. 74-80. 
Sinta Diana Martaulina. 2018. Bahasa Indonesia Terapan. Yogyakarta: Cv Budi Utama.

Siswati, S. (2010). Minat membaca pada mahasiswa (studi deskriptif pada mahasiswa fakultas psikologi UNDIP semester I. Jurnal Psikologi Undip. Vol. 8, No. 2, h. 124- 134.

Sitti Aminah Etall. 2020. Bahasa Indonesia Untuk Perguruan Tinggi, Banda Aceh: Lembaga Kita.

Slameto. 2003. Belajar dan Faktor-faktor yang Mempengaruhinya. Jakarta: Rineka Cipta.

Slameto. 2015. Belajar dan Faktor-faktor yang Mempengaruhinya. Jakarta: PT. Rineka Cipta.

Soekono wirjosoedarmo. 1984. Bahasa Indonesia. Surabaya: Sinar Wijaya.

Sugiyono. 2012. Metode Penelitian Kombinasi. Bandung: Alfabeta.

2010. Metode Penelitian Pendidikan ( pendekatan kuantitatif, kualitatif, dan R\&D).

Bandung: Alfabeta.

Suharmono Kasiyun. 2015. Upaya Meningkatkan Minat Baca Sebagai Sarana Untuk Mencerdaskan Bangsa. Jurnal Pena Indonesia (JPI), Vol. 1, No. 1.

Suharmono. 2015. Upaya Meningkatkan Minat Baca Sebagai Sarana Untuk Mencerdaskan Bangsa. Jurnal Bahasa Indonesia, Vol. 1, No.1, h. 5.

Sujdana. 2019. Penilaian Hasil Proses Belajar Mengajar. Bandung: Remaja Rosdakarya.

Sukardi. 2014. Metodologi Penelitian Pendidikan Kompetensi dan Praktiknya. Jakarta: Bumi Aksara.

Tim Penyusun Kamus Pusat Bahasa. 2008. Kamus Bahasa Indonesia. Jakarta: Pusat Bahasa.

Tri Ani. 2010. Internalisasi Lecerdasan Emosional Dalam Pembelajaran Pendidikan Jasmani Olahraga dan Kesehatan. Jurnal Pendidikan Indonesia, Vol. 7, No. 1, h. 7.

Triatma, I. N. (2016). Minat baca pada siswa kelas VI sekolah dasar negeri Delegan 2 Prambanan Sleman Yogyakarta. E-Jurnal Prodi Teknologi Pendidikan, V(6), h. 166178. 
Wiboowo, Nugroho. 2016. Upaya Peningkatan Keaktifan Siswa Melalui Pembelajaran Berdasarkan Gaya Belajar Di Smk Negeri 1 Saptosari. Jurnal Electronics, Informatics, and Vocational Education (ELINVO), Volume 1, Nomor 2.

Winda Azmi. 2019. Pengaruh Minat Baca Keterampilan Menulis Teks Eksplanasi Siswa SMA Negeri 1 Lembah Melintang. Jurnal Bahasa, Sastra, dan Pengajarannya. Vol. 3, No. 2, pp. 192. 